\title{
A SPECTRE IS HAUNTING SWEDISH ARCHAEOLOGY - THE SPECTRE OF POLITICS Archaeology, Cultural Heritage and the Present Political Situation in Sweden
}

\author{
Anders Gustafsson \& \\ Håkan Karlsson
}

\begin{abstract}
Today Swedish archaeology and cultural heritage management are embraced by the xenophobic party Sweden Democrats. This is a problematic situation, and once again it is therefore time to discuss the relationship between archaeology, cultural heritage and politics - not as a consequence of theoretical considerations and standpoints, but against the background of the harsh political reality. The overall aim of this paper is to contribute to the discussion concerning which strategy, or strategies, Swedish archaeology and cultural heritage management should adopt as a response to the present political situation and as a defence of a solidaristic and multicultural Swedish society
\end{abstract}

Keywords: Archaeology, cultural heritage, cultural heritage management, politics, xenophobia, multicultural strategy

\section{BACKGROUND}

We will have to see, it's the politics that determine. I'm not determining, we will have to see what the politics lead to (our translation).

This was the answer given by the director-general of the National Heritage Board, Inger Liliequist, in the Swedish news programme Rapport 
on 2I November 2010 when asked how she viewed the fact that the party Sweden Democrats (SD) (Sw. Sverigedemokraterna) wanted to increase the support to associations, organizations, authorities and institutions that aim at preserving and stimulating the Swedish cultural heritage (Rapport 20IO-II-2I). For various reasons this answer is too defensive, and both the director-general and we as archaeologists and cultural heritage managers need to be able to give a much clearer answer to the question how we view the fact that this party embraces and wants to support us.

The Sweden Democrats (SD) is an ultra-right-wing party with a xenophobic standpoint, and the present immigration and integration policies in Sweden are the main issues on its agenda. In the Swedish parliament elections that were held in September 2010 the party received approximately $5.7 \%$ of the total number of votes and as a result entered the Swedish parliament for the first time. The party also holds the balance of power since the results of the election meant that the coalition between the centre and right-wing parties could only create a minority government. The Swedish political landscape has thereby been radically altered, since until now - with the brief exception of the populist New Democracy Party during the period I99I-I994 - the Swedish parliament has been spared from ultra-right-wing parties. Furthermore, from now on Sweden also has to face a situation that is common in a number of European countries where parties with various "brownish" nuances are established in the parliaments. In the Swedish case this implies that the conditions for all forms of societal activities dependent on governmental support, not least archaeology and cultural heritage management, have been radically altered.

Concerning central political issues and fields, SD will probably have a minor influence, but the risk is that certain fields which the leading political parties view as being of lesser value and thus unimportant can come to be dominated and expropriated by this extremist party. One such field is cultural heritage and the questions connected with it. SD shows a profound interest in this field and its possibilities to promote the party's xenophobic politics of excluding various persons and groups in the Swedish society as "non-Swedish" on account of their cultural background or their cultural preferences; that is, the party wants to construct an imagined identity of "Swedishness" with the help of the past and its material culture. In line with this, SD wants to increase the support to associations, organizations, authorities and institutions that aim at the preservation and stimulation of the Swedish cultural heritage, which SD views as neglected and threatened by the broadly accepted Swedish political agenda of multiculturalism (SD 20IOa). This means that we as 
archaeologists and cultural heritage managers suddenly find ourselves embraced and supported by a political party whose ideas most of us probably do not share. This is a contemporary political situation that a number of us, not least the director-general Inger Liliequist, as it seems, find very problematic, and the question is how the future of archaeology and cultural heritage management will look under these premises during the next three years of the present mandatory period (the present period runs from 2010 to 20I4). There are, of course, a number of possible strategies that can be adopted in this situation, and interestingly some of these strategies also go hand in hand with already existing trajectories, standpoints and discussions within Swedish archaeology and cultural heritage management concerning the relationship between archaeology, cultural heritage, and contemporary society and its politics.

Once again, it is therefore time to highlight the discussion concerning the intertwined relationship between archaeology, cultural heritage and politics, but this time the discussion is not solely a consequence of theoretical considerations and standpoints. Instead it is a necessity forced upon us archaeologists and cultural heritage managers by the conditions of the harsh political reality. This reality forces us to act in one way or another and to give straightforward answers concerning our view of being used within the framework of the policies of a xenophobic party. Thus, the aim of this paper is to:

- contribute to the discussion concerning which strategy, or strategies, Swedish archaeology and cultural heritage management should adopt in relation to the existing political situation where the ultra-rightwing party SD embraces and supports our activities, at the same time as this party wants to use both us and cultural heritage in the service of its xenophobic policy

- discuss some of the present standpoints within Swedish archaeology and heritage management concerning the relationship between archaeology, cultural heritage, and politics, and how these standpoints can be adopted as strategies of their own or as a common strategy, as a response to the present political situation and as a defence of a solidaristic and multicultural Swedish society

The paper starts out with a brief background concerning the issue of archaeology, cultural heritage and politics, and thereafter SD's strategy concerning cultural heritage is briefly examined and discussed. This background is followed by a discussion focusing on what we mean is low-key trench warfare taking place within Swedish archaeology and heritage management between different standpoints concerning the societal and political roles of archaeology, cultural heritage management 
and cultural heritage. We focus especially on how this trench warfare shows itself within the framework of the present research policy. Finally, the question of how these standpoints can be adopted as strategies in the present political situation is discussed.

\section{THE NEVER ENDING STORY - THE CONNECTION BETWEEN ARCHAEOLOGY, CULTURAL HERITAGE AND POLITICS}

During the last decades archaeological research, not least the field of history of archaeology, has shown that antiquarianism, the discipline of archaeology, and cultural heritage management have always been influenced by, and influenced, politics in one way or another. This connection is so strong that the question is whether the discipline of archaeology and its activities would have been created and developed, and would have existed today, if it were not for this strong bond (cf. Trigger 1989; Díaz-Andreu 2007; Murray \& Evans 2008). It is easy to accept the connection between archaeology and politics when examining the history of the discipline and its activities, but in the present situation it is not always easy to be aware of and find a strategy concerning its existence. However, on a general level the bond is always there! During history it has taken on a variety of forms and sometimes, for instance regarding Nazi Germany, it is easy to trace the connection (cf. Arnold I992; Härke ed. 2002) while in other contexts, such as in Sweden up to the last election, it is more complicated. However, during the last decade the research carried out in Sweden concerning the relationship between archaeology, cultural heritage management, society and politics shows that a political dimension is always embedded in the activities and narrations of Swedish archaeology and cultural heritage management, and that this has been the case from the I 7 th century until today (cf. Grundberg 2000, 2004; Pettersson 200I, 2003; Aronsson 2004, 2006; Aronsson \& Hillström eds 2005; Alzén \& Aronsson eds 2006). It is also interesting to approach this dimension in retrospect since one can easily conclude that a more profound political (and economic) support to disciplines and activities that handle the past and the cultural heritage solely exists in situations where political forces strive for control over the interpretations of the past for various political agendas. Most often this implies a situation where a constructed identity or community is desired in a certain society. This community can be constructed on local, regional or (in most cases) national levels to implement a "we" and a "them" and it can, for instance, be used for gathering, and in the end forcing, people to react 
to an imagined inner or outer societal threat, that is, a constructed and/ or imagined threat that can consist either of other nations or of ethnic groups or classes within the own society (cf. Anderson 1983; Gellner I983). In short, this means that times of prosperity for archaeology are synonymous with times of unpleasant, xenophobic and/or nationalistic, societal and political conditions. The list of examples of this situation from different time periods, political agendas and places around the world can be made long. In this context it is perhaps interesting to note that the most profound "all time high" for archaeology (at least when it comes to political and economic support) existed in Nazi Germany. Here, past cultural remains, historical greatness, and the modern German people and their culture were connected in uncomplicated and simplified manners that led to the construction of an imagined national identity/community where culture and ethnicity (i.e. race) became the link to both the past and the cultural heritage as well as the support for arguments of territory and racial superiority (cf. Arnold I992; Härke ed. 2002). As we shall see below, there are clear reminders of this simplified reasoning in SD's rhetoric concerning the cultural heritage. Of course, the same can also be said about the rhetoric used in claims made by different indigenous groups, even if the purpose of these latter claims is not nationalism or national identity but rather a question of using the past and archaeology politically in recuperation and emancipatory identity creations (cf. Layton ed. 1994; Wobst \& Smith ed. 2005; Hart, Wobst $\&$ Bruchac eds 20I0). The German example and the political use of the past and archaeology in the Nazi propaganda are also interesting from another point of view, namely their influence on the handling of the question of archaeology and politics after the Second World War. The theoretical and methodological development that took place in archaeology between the I950s and I970s can at least partly be ascribed to a search for politically neutral scientific procedures that could ensure that the idealistic use of the past and archaeology could never again be repeated (Binford 1987, 1989; Moberg [1947]1984; Malmer 1984). Thus, one reason for the scientific orientation, on behalf of the traditional cultural historical approach, as well as the rigorous methodological procedures within the processualism of the New Archaeology was - at least partly - to try to find a constructive way to handle the relationship between archaeology and politics (ibid). Of course, this orientation, and its interpretations and production of knowledge, was in itself political (and a political standpoint) and it soon became evident that it had some undesired scientific as well as political implications. One of the trajectories of criticism that has been directed towards processualism since the mid-1970s by critical Marxists and post-structuralist researchers is 
that it is impossible to hope for and to search for an apolitical archaeology that can produce neutral and objective knowledge through its scientific methods (cf. Shanks \& Tilley 1987a, 1987b). From these standpoints it has been argued that it is better to accept that archaeology is always political to its nature and better to act accordingly; that is, it is better to clearly declare why the past is interpreted and understood in one way and not in another and to accept the political implications of different interpretations. This means that the political bond is unavoidable and that archaeology - as with all science - is always a form of politics and that we must decide which kind of politics we want to support (ibid). This is the explanation underlying the situation - which some see as a paradox - whereby some archaeologists can criticise the use of the past for the construction of an imagined national identity/ community at the same time as they support the use of the past by different indigenous groups in emancipatory identity creations. In neither case are there clear-cut connections between the past and the present, and it is rather a question of for which strategic political purposes the past is interpreted and used in the present - political purposes that one can criticise or support in accordance with one's political standpoint (see e.g. Smith 2004 for discussion).

During the last four decades, Swedish archaeology and cultural heritage management have been influenced by these different theoretical discussions in various ways and to various degrees. Even if the traditional cultural historical approach - in a broad sense - has continued its main dominance in all sectors of Swedish archaeology, the academic research and education have at the same time been influenced by various theoretical and methodological perspectives (see Herschend I998; Welinder 2003; Baudou 2004 for discussion and references). Within the activities of development-led archaeology, the methodological ideas of processualism had, in a "milder" version, a rather quick impact already from the beginning of the I970s and onwards since these ideas went hand in hand with the development of the technical and instrumental aspects of the excavation activities. Within the framework of the cultural heritage management, traditional ideas were largely dominant until the I990s, when various ideas concerning the interpretative dimensions inherent in the understanding of cultural heritage were developed; and from the beginning of the 2 Ist century this field has seen the search for a clear political standpoint concerning the use of cultural heritage in the service of democracy and multiculturalism (RÄ̈ 2004a-c, 2005). In short, then, this implies that during the last four decades there has been a reawakened interest in, and awareness of, the political dimensions of archaeology and cultural heritage management. Today nobody work- 
ing within these fields can be unaware of the political and constructivist dimensions inherent in the interpretation and understanding of the past. At this point it may suffice to conclude that there seems to be a general acceptance of the connection between archaeology and politics within Swedish archaeology, but as we shall see below there are profound differences between the standpoints when it comes to questions such as the following: Is this connection unavoidable or not, should archaeology and the cultural heritage be used to support specific political ideas in contemporary society, and, if so, what kinds of ideas?

Anyhow, before approaching these questions let us turn to SD's view of cultural heritage, since in this view there are no questions whatsoever concerning the standpoint that archaeology and cultural heritage are political and that it can be used for specific political purposes. Let us therefore briefly examine and discuss SD's view on cultural heritage, not least since it is a good example of how the cultural heritage is political and how this party wants to use it for specific political purposes.

\section{CULTURAL HERITAGE IN THE SERVICE OF XENOPHOBIA}

As mentioned above, SD wants to increase the support to associations, organizations, authorities and institutions that aim at the preservation and stimulation of the Swedish cultural heritage. This is because the party regards the Swedish cultural heritage as neglected and threatened by the broadly accepted Swedish political agenda of multiculturalism (SD 20IOa). As archaeologists and cultural heritage managers we need to question this sudden interest in cultural heritage and in our activities, as well as examine the underlying strategy behind this interest. Let us therefore briefly look at some of SD's central ideas. So far, the discussions about SD have mainly focused on the party's xenophobic view of the present immigration and integration policies, as well as on their simplified manner of comparing various economic areas and interests with other, for instance the costs of the existing immigration policy on the one hand and the costs of the care of the elderly on the other. However, as pointed out by Björn Magnusson Staaf, it is important to notice that the increased support that the party proposes for activities aiming at the preservation and stimulation of the Swedish cultural heritage solely is another, rhetorically and strategically more sophisticated way to promote the party's xenophobic and exclusive policies (Magnusson Staaf 20IO). That this is the case is quite easily concluded if one reads the party's central policy documents. In these SD presents itself as a na- 
tionalistic value-conservative party with influences also from the ideas of the Swedish welfare state, and it stresses that the primary aim of its politics is to:

/.../ restore a common national identity and thus also a stronger internal solidarity within the Swedish society. The party distances itself from multiculturalism /.../" (SD 2orod:I, our translation).

This is because

The most important factor in a secure, harmonious and solidaristic society is the common identity, which in itself is a prerequisite for a high degree of ethnic and cultural commonness amongst the population (SD 2010b:4f, our translation).

However, SD's national-romantic dreams of a common Swedish national identity and a harmonious (culturally "pure Swedish") society are, in its own world-view, at the same time threatened by the present Swedish immigration and integration policies as well as by the reigning policy of multiculturalism since

Sweden has received far too many immigrants in a short time /.../The mass immigration together with the high nativity among certain groups of immigrants and the absence of an assimilation policy means that the Swedes within a few decades run the risk of becoming a minority in their own country. This development will affect all aspects of the society and change our country beyond recognition (SD 20I0c:5, our translation).

These brief quotations collected from some central SD policy documents, which contain a great deal more of the same xenophobia, clearly explain why immigration and multiculturalism are seen as sincere threats to the idea of a Swedish society consisting of "pure Swedes" that is advocated by the party. The quotations, as well as the documents on the whole, also show that it is completely accurate to label this party both xenophobic and exclusive in character.

The cultural heritage has a crucial role to play in the above-described process, and in SD's documents it is stressed that, among other things.

The primary aim of the cultural policy is to strengthen the interest in and knowledge of Swedish and local culture as well as to preserve the profound values that the cultural heritage contains (SD 20I0c:I2; SD 2010e:7, our translation).

Furthermore, on the party's website, under the heading Let Sweden be Sweden, it is stressed that 
In today's Sweden the Swedish cultural heritage and the Swedish identity are neglected and denied on behalf of foreign cultures. In today's Sweden too much of the cultural support that is financed via taxes is channeled to multicultural, destructive and elitist cultural manifestations (SD 20Iоa, our translation).

At the same place, as well as in the party's main programmes, it is also stressed that the party ought to change this situation by increasing the support to associations, organizations, authorities and institutions that aim at the preservation and stimulation of the Swedish cultural heritage. In addition, the party - with inspiration from Denmark - will start a process that will lead to the acceptance of a cultural canon that lists indispensable and significant examples of the Swedish culture. It is further stressed that it is important that the cultural sector has a broad public anchorage at the same time as activities that support a multicultural society shall be liquidated (SD 20I0a, 20Iob).

As can be seen, the cultural heritage is once again to be put to service in the construction of a common national identity, a national identity that in the SD version will be an imagined community of "Swedishness". As shown earlier this is an old strategy that has been used with success throughout history. In the specific case, and from an SD point of view, it is probably a far more fruitful strategy than to attack the immigration and integration policies, or the immigrants, directly. The reason is that the same effect can be achieved by the use of the cultural heritage and the construction of an imagined Swedish identity that excludes a number of people from this common identity. Of course, the traditional strategy of attacking and discrediting immigrant groups directly can be used in parallel, see for instance the Islamophobic arguments used and the fear of Islamic terror underblown by SD (SD 20Iof).

In this context SD also has "inspiring" examples to follow from other parts of Europe where its xenophobic sister parties have been using the same rhetoric and strategies for decades, see for instance Front National in France and National Front in the UK. In this context, however, the Danish example is perhaps more illuminative since the xenophobic and Islamophobic Danish People's Party (Dan. Dansk Folkeparti) has been successful with regard to the right to define what should be accepted as Danish culture at the same time as the party during the last decade has become a powerful factor in Danish politics. For instance, in 2004 the party succeeded in getting political support for a Danish cultural canon that lists indispensable and significant examples of the Danish culture. Despite sharp criticism this canon was published in 2006 (Krabbe Hammershøy, Viking \& Høvring 2006). In Denmark the whole idea 
was criticised as being, among other things, an oversimplified way of embracing culture and a tool for nationalism within the framework of an outdated romantic view of culture (cf. Bock 2004; Nielsen 2004). So, it is not surprising, as we have seen above, that $\mathrm{SD}$ also stresses the necessity of a Swedish cultural canon. By highlighting this question, the party is trying to dominate and expropriate the right to define what should be accepted as Swedish culture and cultural heritage. A cultural canon seems to be a perfect tool when distinguishing between which phenomena and activities ought to be accepted as parts of the Swedish culture and cultural heritage. The borderline between a 'we' and a 'them' is also inherent implicitly in this rhetoric since the canon can easily show which phenomena are Swedish and who is Swedish to his/her nature. The celebration of Christmas (even if not a Swedish tradition in its origin) will probably take its place in the canon but we can be sure Ramadan will not. In short, the canon is both an instrument to link the present to an imagined Swedish past and a tool that gives the Swedes the right to decide what should be considered as Swedish and Swedishness, or in SD's rhetoric:

Let all people be masters in their own house (SD 20I0b:5, our translation).

It is also easy to imagine a future where this proposed canon can be used in the service of a prohibition of non-Swedishness and that it can be a powerful tool in the obligatory citizenship test and the declaration of loyalty that SD advocates for persons applying for Swedish citizenship (SD 20I0d:6). In October 20I0, and in connection with the parliamentary handling of the cultural budget, SD motioned about: I) more resources to support associations, organizations, authorities and institutions that aim at the preservation and stimulation of the Swedish cultural heritage (Motion 20IO/II: $\mathrm{Kr}_{3} 20$ ), and 2) the construction of a Swedish cultural canon (Motion 20I0/Ir:Kr3IO). Not surprisingly, the resources for this, according to SD, should be taken from a downprioritizing of international and multicultural activities in the cultural budget. However, in the cultural committee's proposal, which was accepted with acclamation by the parliament, both these proposals were downplayed (Kulturutskottets betänkande 20I0/I I:Kr UI). However, $\mathrm{SD}$ will probably continue the battle in various forms since the cultural heritage, as we have seen above, is central for its strategy. In this context it is also interesting to note that $\mathrm{SD}$ is not standing completely alone since the idea concerning a cultural canon has also been presented earlier by the Liberal Party (Sw. Folkpartiet) (Samråd om kulturpolitiken 2007:5). Needless to say, the Liberal Party's aims with such a canon are different from those of SD, but the effects can be the same. 
SD's reasoning with regard to the cultural heritage is anchored in a number of fundamental romantic simplifications, since neither the past nor the cultural heritage is constituted in the manner that $\mathrm{SD}$ argues. Of course, there is no straightforward ethnic link between people living in Sweden today, this geographical region's past and the people that once lived there, and a specific cultural heritage. This is because the imagined Swedish culture and the cultural heritage have not developed organically and in a straightforward manner over thousands of years. Rather, they have been influenced by migrations and the diffusion of items, people and ideas. Thus, Swedish cultural heritage is not something that is fixed and static once and for all; instead it is a many-sided process of multicultural interaction between a number of cultural manifestations, forms and impulses over time. There is also an ongoing process of interpretation where different time periods and societal contexts choose different perspectives in, and on, this process. Rather ironically, this means that the persons advocating SD's view of cultural heritage have a lot more in common with present-day immigrants from various parts of the world than they ever can have with historical persons once living in the geographical region we now call Sweden. Cultural heritage and the past expand in so many multicultural directions and have been influenced by so many different happenings and phenomena that they cannot be forced inside the simplified cage that SD proposes.

However, since the interest in the past and in cultural heritage is widespread in today's Sweden, SD has here found a way of packaging and promoting its xenophobic and exclusive ideas in a seductive form. This at the same time as its ultimate goals and politics remain, of course, unchanged. At a general level this situation is quite harmless as long as the larger political parties view questions concerning the field of cultural heritage as politically relevant. As long as this is the case the doors for a nationalistic use of cultural heritage are closed, such as in the case of SD's proposals concerning a cultural canon. The question, however, is how long the cultural heritage and activities that follow from it will be seen as politically relevant. This is a central question, not least because we as archaeologists and cultural heritage managers in many cases seem eager both to suppress and to avoid the political dimensions of archaeology and cultural heritage. Today, however, in view of the present political reality, the question is how we as archaeologists and cultural heritage managers should act in this situation and which strategies we should adopt. It can be stressed that the wish to strengthen the democratic society with the help of cultural heritage, a view that was advocated both in Agenda Cultural Heritage (see below) as well as in this text, contains a paradox. This is because SD has risen to power within a democratic 
process where they received $5.7 \%$ of the total number of votes in the latest election, and that they used the cultural heritage in their rhetoric to achieve this result. However, the problem is not only that SD uses an oversimplified romantic view of cultural heritage or that they wish to use it for a xenophobic and exclusive policy, but also that we indirectly have helped them on the way since we have not problematized cultural heritage and its political dimensions enough in our activities and our research. The success of SD, as well as of other xenophobic and exclusive parties around Europe, is a consequence of general socio-political trends where many people seem to feel disoriented in a more globalised world in which the institutions of the national state that once offered security and stable identities are now fragmented. Stability in the form of tradition and traditional values seems to be the lifesaver for many persons, and in the Swedish case this shows itself in a cry for an imagined Swedishness. Probably it is not primarily the cultural heritage questions that have drawn people to $\mathrm{SD}$, but if cultural heritage is seen as something stable and never changing, with connections to a secure and traditional past, it will be used as a tool for the parties that feed themselves on people's insecurity. The question is what we as archaeologists and heritage managers have done to problematize the past and what we can do to create security in a globalised world by using cultural heritage in an inclusive manner and for strengthening a solidaristic and multicultural society. Here, a huge and important field for future research is opening up.

\section{THE LOW-KEY TRENCH WARFARE WITHIN SWEDISH ARCHAEOLOGY AND CULTURAL HERITAGE MANAGEMENT}

In 2004 one of the authors of this text wrote an article in which it was stressed that there exist various theoretical standpoints within Swedish archaeology and that this is the way it should be, since different approaches and opinions are necessary for the development of the subject through scientific discussion and debate. At the same time it was stressed that there is a need to get rid of exaggerated polarizations on behalf of a realization that there is no single theoretical standpoint that is more 'archaeological' than others and that we as archaeologists can together face the challenge of different archaeological theories put into practice, both in the field and in society as a whole. It was concluded that this was the way to get archaeology moving into the 2ist century (Karlsson 2004a:I4). Even if this is just as true and necessary now as it was then, the common ground sought for in the text has not been real- 
ized; rather, it has been the other way around. Nobody, or at least not the author of the text cited above, could have foreseen the outburst that was to come in 2004-2005 within the framework of the struggle over which role archaeology, the past and cultural heritage should have in the Swedish society. These years were to become a turbulent period within Swedish archaeology and cultural heritage management since different standpoints concerning the political role of archaeology, cultural heritage and the cultural heritage management sector collided. The background is to be found in the political realization that neither the heritage management sector nor the cultural heritage is, as before, expected to fulfil their duty within the limited framework of a process of nationalistic identification in which the protection of a canonical - and pinned down - cultural heritage is the only central task. One of the points of ignition was the unique project Agenda Cultural Heritage ( $S w$. Agenda kulturarv) that was carried out between $200 \mathrm{I}$ and 2004 and in which the National Heritage Board, county museums and county administrations in cooperation - and in line with the political directives - tried to find a common ground to broaden the content of the concept of cultural heritage, engage the public in the work with cultural heritage, and strengthen a democratic and sustainable societal development and a multicultural society (RAÄ $2004 \mathrm{a}-\mathrm{c}, 2005$ ). In short, these changes focused on the fact that the cultural heritage should not solely be protected and preserved; rather, it should also be used by the public in such a way that the public participates in this process, and as a result the cultural heritage can contribute to democratic processes and a social sustainable development. Thus, the public's commitment and engagement in and for the cultural heritage are essential to both the preservation and the use of it (ibid). These changed attitudes tended to solve a central problem, namely the fact that the public has been excluded from the selection and creation of their own cultural heritage and thus also from the selection and creation of society's collective memories. Within the framework of the new orientations a situation is created whereby the activities are carried out together and in a living and open dialogue with the public. At least in the Swedish context this also means that a harmony is created between juridical statutes and policy documents that highlight the central role of the public concerning the selection and creation of the cultural heritage (Reg. Prop. 1996/97:3). Another point of ignition was the changed attitudes within the board of the National Historical Museum and its orientation of the museum in a direction where the museum and its cultural heritage would be used in exhibitions of value for contemporary socio-political questions (Berg 2003). From one point of view this was post-processualist theories put to practice, but it was also the 
direct consequence of political directives in the governmental cultural policy (Reg. Prop. 1996/97:3). Of course, it was not easy to implement these ideas in practice within different parts of the heritage management sector, since traditional values and ways of working (for instance in milieus with a traditional view on cultural heritage) were challenged by new ideas and demands.

There were also immediate and critical reactions to this change of direction and towards the new political role proposed for cultural heritage and the cultural heritage management sector. The criticism came from defenders of the antiquarian sector's traditional aims and methods, of cultural heritage's primary role as a source of knowledge of the past, and a traditional theoretical focus on empiricism and cultural history. For instance, it was stressed that this contemporary-directed political orientation threatened traditional ideals, that knowledge concerning the past was sacrificed on the altar of contemporary politics, and that the scientific integrity was threatened. The critics could be found in the heritage management sector, but they were primarily found in the archaeological departments at the universities, and a number of persons from the academic world also left their commissions as experts in antiquarian boards and museum boards as a protest against the development. The critics of the new agenda, fully aware of the political dimensions of archaeology and cultural heritage, probably felt that if these dimensions were suppressed and avoided archaeology would not run the risk of being misused politically. The sometimes heated debate between advocates of the two standpoints concerning the role of archaeology, heritage management and cultural heritage in contemporary politics took place internally but also on debate pages in the media (cf. Burström 2002, 2003; Rentzhog, Arrhenius \& Trotzig 2002; Lönnroth 2003; Bohman 2003; Myrdal 2003; Rentzhog 2003; Gustafsson \& Karlsson 2004a; Jacobsson 2004; Johansen, Lindgren, Lindvall \& Viirman 2004; Karlsson 2004b; Liliequist 2004; Tollin 2004a-b; Harding 2005; Roslund 2006; Myrdal $\&$ Bohman 2007). It was an open debate that was fought quite cleanly and fairly, but what happened then? Quietness!

The official quietness regarding these crucial questions, which has reigned since 2007 , should not, however, lead anyone to believe that the struggle between these standpoints has ended. Rather, the difference is that the debate is no longer official. Our research shows that during the period 2000-20I0 it was carried out in parallel within another arena. One example of this is the way in which the research resources are controlled. The academics who defend the antiquarian sector's traditional aims and methods and cultural heritage's one-sided role have been able to control the resources available for research on the past and the cul- 
tural heritage through their academic legitimacy and through their role in various drafting and decision-making committees that decide over the research support to the humanities and social sciences, e.g., at the Swedish Research Council (Sw. Vetenskaprådet), the National Bank of Sweden Tercentenary Foundation (Sw. Riksbankens jubileumsfond), and in stakeholder organizations such as the Royal Swedish Academy of Letters, History and Antiquities (Sw. Kungliga Vitterhetsakademien). Within these organizations they have been able to direct the archaeological research concerning the past and cultural heritage in what we mean is a conservative direction in which traditional questions and problems are focused on instead of a broader view of cultural heritage and the relationship between archaeology, politics and contemporary society.

As a result, a majority of the archaeological projects that have received support from the Swedish Research Council and the National Bank of Sweden Tercentenary Foundation during the period 2000-2010 are, even if dressed in new splendor and vocabulary, frightening reminders of questions and problems that were innovative in Swedish archeology at the end of the Igth century.

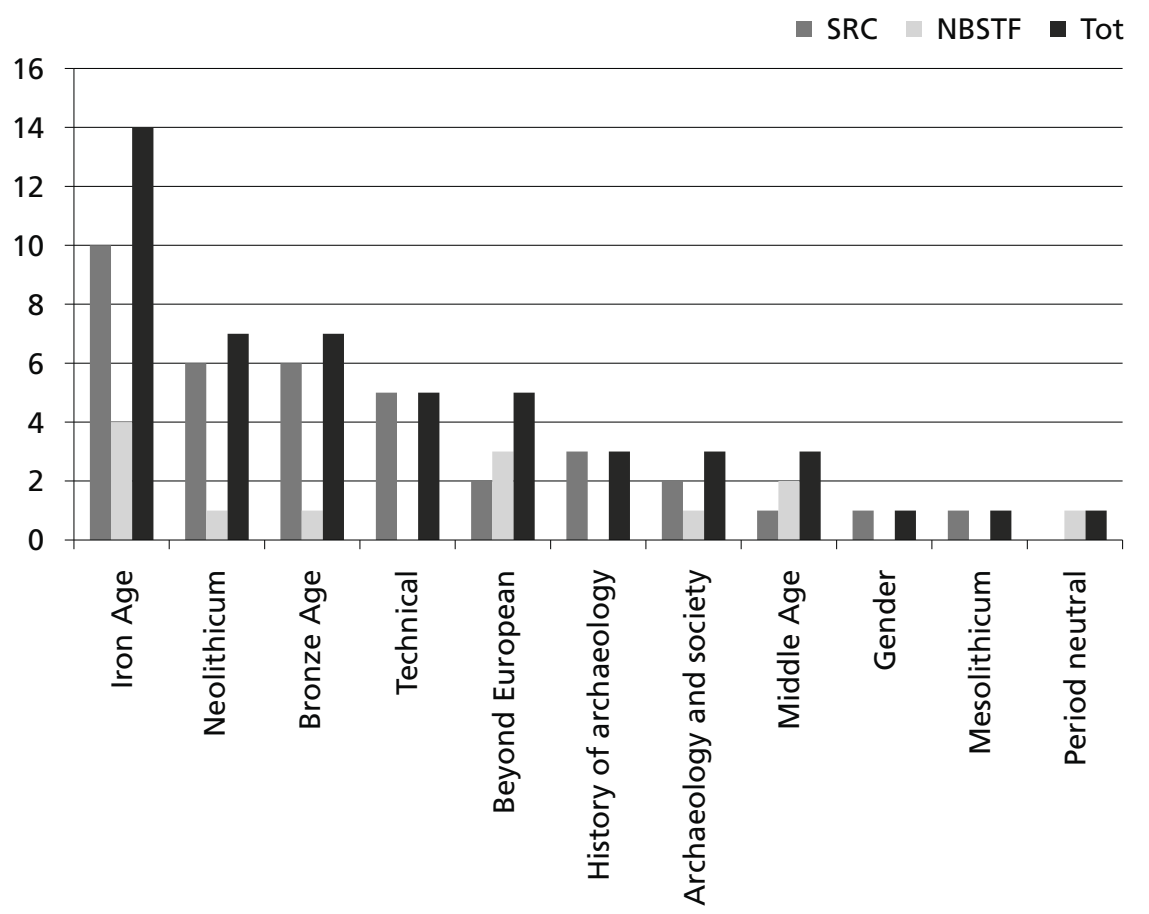

Figure I. Research direction in a total of 50 archaeological projects supported by the Swedish Research Council (SRC) and the National Bank of Sweden Tercentenary Foundation (NBSTF) during the period 2000-2010. 


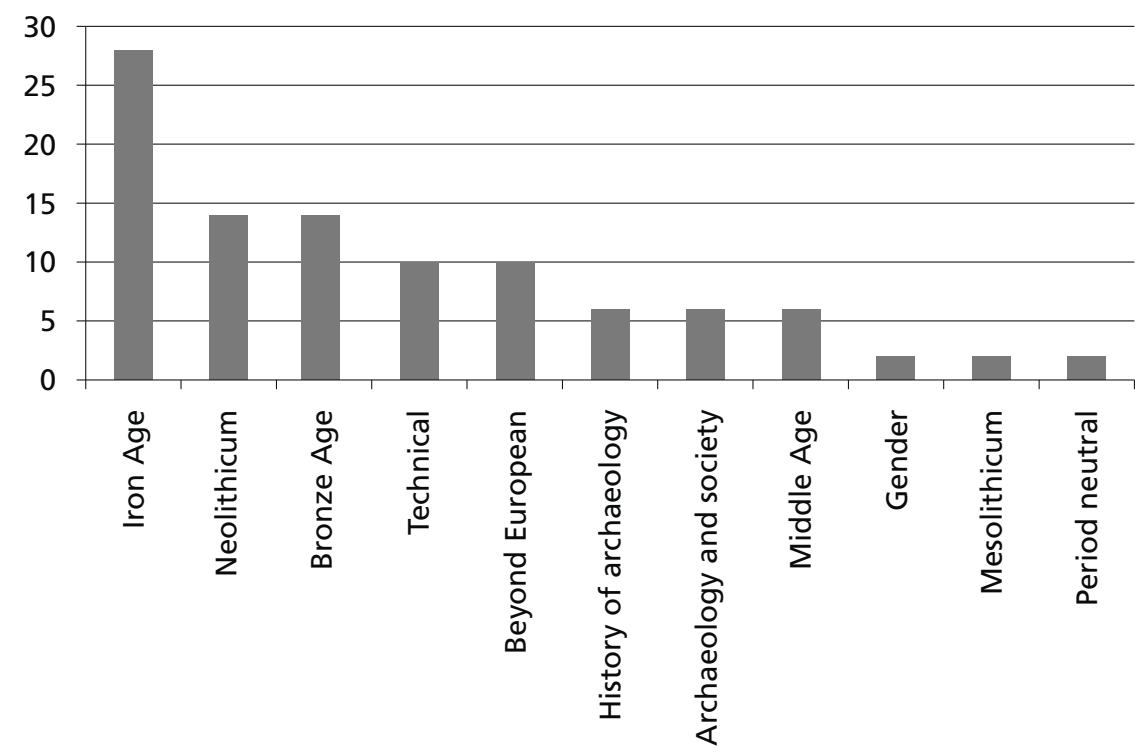

Figure 2. The same information as in figure $\mathrm{I}$, but presented in the form of percentages.

Figures I and 2, which are based on information from the websites of the Swedish Research Council and the National Bank of Sweden Tercentenary Foundation, show that it is still archaeological research on phenomena in certain chronological periods and the Swedish past and its cultural heritage that is in focus and receives support (47 out of 50 projects). On the other hand, only a small number of projects ( 3 out of 50) that approach questions concerning archaeology, cultural heritage and society in a broad sense have received support. In the statistics, projects, post-doctoral work, group grant projects, and support for excellent researchers have been included, while support for conferences, workshops, publishing and infrastructure (labs etc.) have been left out. In short, the statistics show that archaeological research concerning questions approaching the relationship between archaeology, cultural heritage and society have definitively not been in focus during the actual period and that this research direction does not seem to be viewed as "real" archaeology. This fact is not surprising against the background of the reasoning above, but it is problematic in that these questions cannot easily be handled by other disciplines since the very specific, detailed knowledge of archaeology gives a more productive base for the research. Unfortunately it does not end there.

During the years 2009 and 2010 the Swedish Research Council received specific resources from the government within the framework of Group Grants for Cultural Research (Sw. Rambidrag för kulturforsk- 
ning), which was a two-year long commitment that is now finished. The core of the group grants was, from our point of view, to focus in a multidisciplinary way on culture and cultural heritage research through an analysis of

I.../ a number of vital problems within the field of cultural heritage" (VR 20I0a, our translation).

In the governmental proposition that preceded the venture the

/.../cultural heritage's importance for the development of the society /.../" and questions concerning "/.../ values and relationships, communication /.../ of cultural heritage ought to be focused on" (Reg. Prop. 2008/09:50, I83, our translation).

As archaeological researchers of cultural heritage we cannot interpret this intention as something else than a wish to broaden and problematize cultural heritage, its content, forms and functions in a historical, contemporary and future perspective, that is, a primary focus on cultural heritage as phenomena and cultural processes and not as remains. This meant a possibility for the Swedish archaeological research on cultural heritage to close in on the international discourse where, for instance, questions concerning cultural heritage's roles and functions in contemporary society, the handling of different forms of fearsome cultural heritage, and the use of cultural heritage in cooperation with local stakeholders are established parts of the archaeological research (cf. Skeates 2000; Carman 2002; Smith 2004, 2006; Layton, Shennan \& Stone eds 2006; Logan \& Keir eds 2009; Smith \& Waterton 2009). This is a direction of research that comes to the fore in international journals such as Public Archaeology, Social Archaeology and Cultural Heritage, which are dedicated to these fields of research. However, this governmental venue came to be bungled. Most of the I4 projects that received support during 2009-20IO (IO in 2009 and 4 in 20IO) focus on questions that fall well inside the framework of the ordinary research announcements in the field of humanities and social science at the Swedish Research Council and they do not approach

/.../ vital problems within the field of cultural heritage" (our translation).

The projects include studies that focus on the documentation of rock art, the agrarian crises during the Late Middle Ages and the I 7 th century, and the use of images in the monastery of Vadstena in the I6th century. These projects are probably of high quality and have profound relevance for their respective area of research, but the questions are whether they 
should have been supported within the framework of the group grants and how they came to be supported.

This brief example of how the research resources are controlled and spread shows that the tiresome low-key trench warfare between different standpoints concerning theoretical issues, the political role of archaeology, cultural heritage and cultural heritage management in the Swedish society is still reigning after ten years. In 2000 one of the authors of this article discussed Swedish archaeology and the 2ist century and stressed the problems of the theoretical gap, as well as the gap in the directions of interest, between, on the one hand, post-processual influenced archaeologists who were on their way to becoming established, and, on the other hand, archaeologists holding positions on the board of foundations and suchlike. It was further stressed that the latter often do not understand the point of the meta-archaeological questions that the former want to analyse and discuss, and that the risk in this situation is that the foundations will primarily support mainstream archaeology whereas projects directed at post-processual questions will be unsupported (Karlsson 2000:I 49). Unfortunately, this is also a good description of the situation today, a situation that has weakened Swedish archaeology and its possibility to deal with questions concerning the relationship between archaeology, cultural heritage and politics, since not enough archaeological research has been (allowed to be) carried out on these themes. Undoubtedly this situation, where the persons dominating the research foundations do not view these questions as scientifically and archaeologically researchable fields, has hampered Swedish archaeology and its ability to research cultural heritage's roles and functions in contemporary society not only on a theoretical and practical level during the period 2000-20I0 but also with regard to its ability to act in the present political situation. However, in this context the National Heritage Board ought to be credited since their Research and Development Resources (Sw. FoU medel) have in a number of cases supported academic research that approaches these issues from a critical point of view (cf. Gustafsson \& Karlsson 2004b-c; Burström 2008). These resources are limited, however, in comparison with the resources available at the Swedish Research Council and the National Bank of Sweden Tercentenary Foundation. In addition the Swedish Archaeological Society's interest in questions concerning ethics and multiculturalism, as seen for instance by the support given to meetings and two anthologies approaching these issues (Karlsson ed. 2004; Burström ed. 2006), ought to be mentioned, as well as the fact that the chairman of the Society has been quick to warn about SD's desire to use cultural heritage for dubious objectives (Magnusson Staaf 20I0). With regard to research, 
however, this means that the archaeological researchers who probably have the best possibilities to study the actual field and its issues have never been given the possibility to carry out this important work. Now it may be time to pay the price for the under-prioritizing and neglect of this research. This is a consequence both of the low-key trench warfare and of the non-acceptance of these questions as academically researchable fields by the persons who have the power to decide over the research resources.

However, putting the theoretical differences aside, it is high time to try to find a common ground where a strategy can be developed for Swedish archaeology and heritage management in relation to the existing political situation.

\section{CONCLUSION: FUTURE STRATEGIES FOR THE USE OF CULTURAL HERITAGE IN A DEMOCRATIC AND MULTICULTURAL SWEDISH SOCIETY}

The problem of accepting questions concerning the political role of archaeology, cultural heritage and cultural heritage management as a field that is scientifically researchable, as well as the low-key war trench warfare and its effects briefly discussed above, has hampered and continues to hamper Swedish archaeology in a number of ways. This concerns not least the ability of archaeology to find relevant strategies in the existing political situation. SD's attempt to muster more resources to support associations, organizations, authorities and institutions that aim at preserving and stimulating the Swedish cultural heritage, as well as the party's desire to construct a Swedish cultural canon, has temporarily been stopped by parliament. However, due to the strategic importance of cultural heritage in SD's xenophobic politics these questions are far from politically dead and will return in various forms and disguises. Most of us probably feel that this is not enough and that it is our duty to stand up against SD's oversimplified views of the past and of cultural heritage, as well as its use of both us and cultural heritage for xenophobic politics. Thus, the question concerning which strategies Swedish archaeology and heritage management should adopt in relation to SD's embrace and support of our activities, and the party's desire to use the past and cultural heritage for its own purposes, is still highly relevant.

As we have seen above, there are two main standpoints and trajectories concerning the relationship between archaeology, cultural heritage, and politics and both of these can be used as strategies. The persons who represent a more traditional view of this relationship, and who hold the 
positions of power concerning research resources, will most probably stick to the opinion that archaeology and politics should not be mixed together. They will mean that the political influences in Agenda Cultural Heritage were a mistake and that this is also the case with SD's intentions to use cultural heritage for its political ideas. Thus, the strategy from this side will probably be a standpoint in line with the argument that SD will not be able to use us or the cultural heritage for their own purposes as long as archaeology and cultural heritage management defend their traditional aims and methods, the view of cultural heritage's one-sided role as a source of knowledge of the past, the non-political involvement in questions concerning the past and cultural heritage, and a traditional theoretical focus on empiricism, cultural history and preservation of past phenomena. However, the real problem with this strategy is that it has backfired. If we as archaeologists and cultural heritage managers try to keep archaeology and cultural heritage outside the political sphere - by lifting forth the same questions as at the end of the I9th century - this strategy will lead to certain, and unwanted, political implications. If we repeat over and over again that our activities should not be mixed up with politics, and at the same time choose to neglect the research on the connection between archaeology, cultural heritage and politics, the risk is great that this field will be viewed by the leading political parties as being of lesser value and thus unimportant and uninteresting. This will open up the way for SD to dominate, expropriate and use this field and the questions related to it. This is exactly the development that has taken place, for instance, in Denmark and that we now run the risk of witnessing in Sweden as well. This means that a strategy that focuses on cultural heritage's one-sided role as a source of knowledge of the past, that suppresses and avoids the political dimensions of archaeology and cultural heritage and that has a traditional theoretical focus on empiricism and cultural history, ironically runs the risk of playing into the hands of SD. This is the case not least since we support them with exactly the unproblematic and stable past that they need in their rhetoric.

The persons who do not avoid the political dimensions of archaeology, and who wish to broaden and problematize the content of the concept of cultural heritage and to use cultural heritage politically for strengthening a democratic, solidaristic and sustainable societal development and a multicultural society, are on the other hand able to muster a completely different strategy where the ideas of Agenda Cultural Heritage are fully implemented and put to practice. This means that once again there is a political use of cultural heritage, but as pointed out above this dimension is unavoidable and it is rather a question of which 
kind of politics should be supported. At the same time there is a need for developed and strengthened research concerning archaeology, cultural heritage and the cultural heritage management sector and the relationship to society and to politics. Within this strategy fruitful alliances can also be constructed between different sectors and actors in society, for instance between various actors within the heritage management sector, this sector and the universities as well as different organizations that have the cultural heritage on their agenda, such as local folklore societies. Organizations such as the Swedish folklore society have already declared that they do not want to be involved in any kind of contact with SD's politics (Nordwall \& Svanström 20Io), and instead they stress the solidarity that comprises all people and cultures in Sweden as well as beyond national borders. Since this strategy does not avoid the political dimensions of archaeology or cultural heritage, it can also meet SD head on with regard to this party's view of cultural heritage and how it should be used. Thus, in this strategy it is not a question of avoiding the connection between archaeology, cultural heritage and politics but rather of taking a standpoint for a democratic, solidaristic and multicultural policy and to use cultural heritage for these purposes. It is also a question of taking back the initiative before SD regroups itself.

Despite the differences between the two strategies briefly presented above, it is necessary that their advocates can find some sort of common ground and a joint strategy. Of course, these strategies can be used singly or in different types of combinations, and it is probably the latter approach that is the most fruitful one. This could for instance be done in line with the points below:

- put an end to the low-key trench warfare, within the framework of a common acceptance of the existence of different ways of working with archaeology and cultural heritage management,

- work for an increase in the support of scientific research concerning, and highlighting, the connection between archaeology, cultural heritage and politics,

- show that the interpretations of the past are always changing due to scientific developments as well as contextual conditions,

- present the societal value of archaeology, cultural heritage management and cultural heritage when it comes to the strengthening of a democratic, solidaristic and multicultural society that in an inclusive manner creates security in a globalised world,

- construct alliances with folklore societies and other stakeholders, and between the universities and the National Heritage Board, 
- implement, continue and develop the work within the framework of Agenda Cultural Heritage,

- promote discussions and debates concerning SD's simplified view of the past and cultural heritage in various media, both from a scientific and a political point of view,

and

- state that archaeology and the heritage management sector never will follow in the lead of a xenophobic party since as humanists we have the responsibility to acknowledge that all persons are of equal worth.

Needless to say, these points should just be seen as proposals - proposals that can contribute to a necessary discussion about the strategies needed for Swedish archaeology and heritage management in the contemporary political situation. That we need a strategy is clear if we are to defend the democratic, solidaristic and multicultural Swedish society. From our point of view this is necessary for us not only as professionals but also as humans. Of course, some of these strategies can be hard to carry out (at least in the future) since both the National Heritage Board and the universities, as well as the Swedish Science Foundation, are dependent on the policies decided about in parliament, a parliament that runs the risk that $\mathrm{SD}$ will become even more powerful in the future. But so far, we are not working under any policy decided by SD, and thus there is still time to act and to stand up against the xenophobia of this party in a defense of a multicultural Swedish society where nobody is denied their human value. Of course, this implies that we do not view the political dimensions of archaeology and cultural heritage as a spectre but as a creative possibility.

Anders Gustafsson \& Håkan Karlsson University of Gothenburg, Department of Historical Studies Box 200, 40530 Göteborg, Sweden

\section{REFERENCES}

Alzén, A. \& Aronsson, P. (Eds). 2006. Demokratiskt kulturarv? Nationella institutioner, universella värden, lokala praktiker. Linköping: Department of Culture Studies.

Anderson, B. I983. Imagined Communities. Reflections on the Origins and Spread of Nationalism. London: Verso.

Arnold, B. I992. The Past as Propaganda: Totalitarian Archaeology in Nazi Germany. Antiquity. Vol 64, No 244. Pp. 464-478. 
Aronsson, P. 2004. Historiebruk. Att använda det förflutna. Lund: Studentlitteratur.

Aronsson, P. \& Hillström, M. (Eds). 2005. Kulturarvens dynamik. Det institutionaliserade kulturarvets förändringar. Norrköping: Tema Kultur och samhälle, Campus Norrköping, Linköpings universitet.

Baudou, E. 2004. Den nordiska arkeologin. Historia och tolkningar. Stockholm: Almqvist \& Wiksell.

Berg, K. 2003. Med begränsade resurser måste man prioritera. DIK-forum 3/o3.

Binford, L. 1987. Data, Relativism and Archaeological Science. Man (N.S.) 22. Pp. 39I-404.

Binford, L. 1989. The New Archaeology, Then and Now. In: Binford, L. (Ed.). Debating Archaeology. Pp. I2-23. San Diego: Academic Press.

Bock, S. Ny liberal kritik av kulturkanon. Politiken. 2004-I2-I6.

Bohman, S. 2003. Bekämpa myten om det dammiga museet. Svenska Dagbladet. 2003OI-07.

Burström, M. 2002. Berg vill få oss att kritiskt reflektera. Svenska Dagbladet. 2002I2-3I.

Burström, M. 2003. Skygglappar för samtiden. Svenska Dagbladet. 2002-I0-оI.

Burström, M. (Ed.). 2006. Arkeologi och mångkultur. Södertörn Archaeological Studies 4. Huddinge: Södertörns högskola.

Burström, M. (Ed.). 2008. Arkeologi i förorten. Berättelser från norra Botkyrka. Södertörn Archaeological Studies 7. Huddinge: Södertörns högskola.

Carman, J. 2002. Archaeology and Heritage. London: Continuum.

Díaz-Andreu, M. 2007. A World History of Nineteenth-Century Archaeology. Nationalism, Colonialism and the Past. Oxford: Oxford University Press.

Gellner, E. I983. Nations and nationalism. Oxford: Blackwell.

Grundberg, J. 2000. Kulturarvsförvaltningens sambällsuppdrag. En introduktion till kulturarvsförvaltningens teori och praktik. Göteborg: Institutionen för arkeologi, Göteborgs universitet.

Grundberg, J. 2004. Historiebruk, globalisering och kulturarvsförvaltning. Utveckling eller konflikt? Göteborg: Institutionen för arkeologi, Göteborgs universitet.

Gustafsson, A. \& Karlsson, H. 2004a. Historiens vaktmästare värnar om en föråldrad roll. Svenska Dagbladet. 2004-04-02.

Gustafsson, A. \& Karlsson, H. 2004b. Platspåscen. Kring presentation och förmedling av fasta fornlämningar i Bohuslän genom tiderna. Uddevalla: Bohusläns museum/ Stockholm: Riksantikvarieämbetet.

Gustafsson A. \& Karlsson H. 2004c. Kulturarv som sambällsdialog. Stockholm: Riksantikvarieämbetet.

Gustafsson, A. \& Karlsson, H. 20Iо. Rambidrag för kulturforskning - en förfuskad idé. Universitetsläraren I9/20I0. Pp.I8-19.

Gustafsson, A. \& Karlsson, H. 20I0. Vår kritik kvarstår på alla punkter och grundfrågorna är obesvarade. Universitetsläraren I/20I I. Pp. I4.

Harding, T. 2005. Museers inlägg måste tåla granskning. Svenska Dagbladet. 2005O2-I7.

Hart, S., Wobst, M. \& Bruchac, M. (Eds). 20Io. Indigenous archaeologies. A Reader on Decolonization. Walnut Creek: Left Coast Press. 
Herschend, F. I998. I förhållande till arkeologi. Uppsala: Institutionen för arkeologi och antik historia.

Härke, H. (Ed.). 2002. Archaeology, Ideology and Society. The German Experience. Frankfurt: Lang.

Jacobsson, M. 2004. Satsningen gynnar allmänheten. Svenska Dagbladet. 2004-02-22.

Johansen, B., Lindgren, J-G., Lindvall, K. \& Viirman, A. 2004. Forntiden har en framtid - om människor tror på den. Svenska Dagbladet. 2004-03-30.

Journal of Cultural Heritage.

Journal of Social Archaeology.

Karlsson, H. 2000. Swedish Archaeology into the 2 Ist Century. The Necessity of (Self) Criticism. Current Swedish Archaeology. Vol 8. 2000. Pp. I43-I55.

Karlsson, H. 2004a. Archaeology's Moral Awakening. An Introduction. In: Karlsson, H. (Ed.). Swedish Archaeologists on Ethics. Pp. 13-20. Bricoleur Press: Göteborg.

Karlsson, H. 2004b. Törnrosas identitetsproblem. En reflektion runt arkeologins och kulturarvsförvaltningens framtida utseende. Arkeologi splittring eller mångfald? Pp. 44-52. http://www.raa.se/publicerat/rapp2006_I.pdf

Krabbe Hammershøy, M., Viking, M. \& Høvring, E. 2006. Kulturkanon. Copenhagen: Kulturministeriet/Politiken.

Kulturutskottets betänkande. 20Iо/I I:KrUI Utgiftsområde I7 Kultur, medier, trossamfund och fritid. www.riksdagen.se/webbnav/?nid=3I $20 \&$ doktyp=betankande $\&$ bet $=2010 \% 2 \mathrm{fII}_{\text {I }} \% 3 \mathrm{aKrU}$ I (2OII-OI-I2).

Layton, R. (Ed.). 1994. Who Needs the Past? Indigenous Values and Archaeology. London: Routledge.

Layton, R, Shennan, S. \& Stone, P G. (Eds). 2006. A Future for Archaeology. The Past in the Present. Walnut Creek: Left Coast Press.

Liliequist, I. 2004. Kulturarvet skall ges en större plats i samhället. Svenska Dagbladet. 2004-03-24.

Logan, W.S. \& Keir, R. (Eds). 2009. Places of Pain and Shame. Dealing with "Difficult Heritage”. Abingdon: Routledge.

Lönnroth, L. 2003. Historiska museet har misslyckats med sin uppgift. Svenska Dagbladet. 2003-I2-02.

Magnusson Staaf, B. 20Iо. Kontroll över kulturarvet SD:s medel för att nå makt. Dagens Nybeter. 2010-10-03.

Malmer, M. P. 1984. Arkeologisk positivism. Fornvännen 79. Pp. 260-268.

Moberg, C-A. [1947] I984. Den nyttiga fornforskningen. En skiss till en åskådnings historia och karaktäristik. Lychnos. Pp. I33-I57.

Motion 20Iо/І г:Kr3 10. Införandet av en svensk kulturkanon. www.riksdagen.se/webbnav/? nid=4Io\&doktyp $=\operatorname{mot} \& \mathrm{rm}=20 \mathrm{IO} / \mathrm{I} \mathrm{I} \&$ bet $=\mathrm{Kr} 3 \mathrm{IO} \& \mathrm{dok} \_\mathrm{id}=\mathrm{GYO} 2 \mathrm{Kr}_{3} \mathrm{IO}$ (2OII-OI-T2).

Motion 20I0/II:Kr320. Utgiftsområde I7 Kultur, medier, trossamfund och fritid. www.riksdagen.se/webbnav/?nid=4Io\&doktyp $=$ mot\&rm $=20$ IO/I I \&bet $=K r 320$ \&dok_id=GYo2Kr320 (20II-OI-I2).

Murray, T. \& Evans, C. 2008. Histories of Archaeology. Oxford: Oxford University Press.

Myrdal, J. 2003. Berg har missuppfattat varför det förs en debatt. Svenska Dagbladet. 2003-OI-O8. 
Myrdal, J. \& Bohman, S. 2007. Museer - mässhallar eller magasin? Nättidningen Svensk Historia. 2007-I I-09.

Nielsen, J. 2004. Georg Metz: regeringens kulturkanon er hyckleri. Politiken. 2004I 2 -I 4 .

Nordwall, J. \& Svanström, B. 20IO. SD:s hembygd är inte vår hembygd. Aftonbladet. 2010-10-02.

Pettersson, R. 200I. Fädernesland och framtidsland. Sigurd Curman och kulturminnesvårdens etablering. Umeå, Univ.

Pettersson, R. 2003. Den svenska kulturmiljövårdens värdegrunder. En idéhistorisk bakgrund och analys. Stockholm, Univ.

Public Archaeology (journal).

Rapport 20IO-II-2I http://svtplay.se/v/224I524/sd_varnar_om_svenskt_kulturarv (2OII-OI-I2).

Reg. Prop. I996/97:3 Kulturpolitik. http://www.riksdagen.se/Webbnav/index. aspx?nid=37 \&dok_id=GKo33 (20II-OI-I 2 ).

Reg. Prop. 2008/09:50. Ett lyft för forskning och innovation. www.regeringen.se/content /I/c6/II/39/57/2f 7I3bd9.pdf (2OII-OI-I2).

Rentzhog, S. 2003. Kärnuppgifter försvinner i förändringen. Svenska Dagbladet. 2003O2-OI.

Renthzog, S., Arrhenius, B. \& Trotzig, G. 2002. Vi vill skapa en samtidsrelation. Svenska Dagbladet. 2002-I2-22.

RAÄ (Riksantikvarieämbetet). 2004a. Agenda kulturarv. Slutrapport. Stockholm: Riksantikvarieämbetet.

RAÄ (Riksantikvarieämbetet). 2004b. Människan i centrum. Agenda kulturarvs programförklaring. Stockholm: Riksantikvarieämbetet.

RAÄ (Riksantikvarieämbetet). 2004c. Kulturarvär mångfald. Fördjupad omvärldsanalys för kulturmiljöområdet 2004. Stockholm: Riksantikvarieämbetet.

RAÄ (Riksantikvarieämbetet). 2005. Kulturarv ger livskraft. Fördjupad omvärldsanalys för kulturmiliöområdet 2005. Stockholm: Riksantikvarieämbetet.

RAÄ (Riksantikvarieämbetet). 20ıo. Tänka i tid. Riksantikvarieämbetets strategi och vision 20I I-20I3. Stockholm: Riksantikvarieämbetet.

Roslund, M. 2006. Mannaminnet räcker inte till. Om arkeologin som politiskt medel för nutid och framtid. Fornvännen гог. Pр. I98-204.

Samråd om kulturpolitiken.www.folkpartiet.se/ImageVault/Images/id_6440/scope_o/ Image VaultHandler.aspx (2OI I-OI-I2).

SD 2оIоa. Làt Sverige förbli Sverige. http://sverigedemokraterna.se/valet-2oIo/lat-sverige-forbli-sverige/ (2OI I-OI-I 2).

SD 2oIob. Sverigedemokraternasprincipprogram. http://sverigedemokraterna.se/varaasikter/ principprogram/ (2OI I-OI-I2).

SD 20Iоc. Kommunpolitiskt program. http://sverigedemokraterna.se/vara-asikter/riktlinjer-for-en-sverigedemokratisk-kommunpolitik/ (2OI I-OI-I2).

SD $20 I 0 d$. Invandringspolitiskt program. http://sverigedemokraterna.se/vara-asikter/ invandringspolitisk-program/ (2OI I-OI-I2).

SD 20Iоe. 99 förslag för ett bättre Sverige. Sverigedemokraternas kontrakt med väljarna 2OIO-20I4. http://sverigedemokraterna.se/vara-asikter/invandringspolitiskprogram/ (2OII-OI-I2). 
SD 20Iof. http://sverigedemokraterna.se/riksdagen/20IO/I2/I6/sd-fick-igenom-kravpa-debatt-om-islamism/ (2OII-OI-I2).

Shanks, M. \& Tilley, C. I987a. Social Theory and Archaeology. Cambridge: Polity Press.

Shanks, M. \& Tilley, C. 1987b. Re-Constructing Archaeology. Theory and Practice. London: Routledge.

Skeates, R. 2000. Debating the Archaeological Heritage. London: Duckworth.

Smith, A. 2004. The End of the Essential Archaeological Subject. Archaeological Dialogues I I (I). Pp. I-20.

Smith, L. 2004. Archaeological Theory and the Politics of Cultural Heritage. London: Routledge.

Smith, L. 2006. Uses of Heritage. New York: Routledge.

Smith, L. \& Waterton, E. 2009. Heritage, Communities and Archaeology. London: Duckworth.

Tollin, C. 2004a. Forntid utan framtid. Svenska Dagbladet. 2004-03-22.

Tollin, C. 2004b. Om vi inte förstår vår egen historia kan vi inte heller förstå andras. Svenska Dagbladet. 2004-04-07.

Trigger, B. G. 1989. A History of Archaeological Thought. Cambridge: Cambridge University Press.

VR 20Iоa. Hantering av särskilda inriktningar 2010 - kulturforskning, rambidrag. www.vr.se/forskningsfinansiering/forgranskare/beredningshandbokhumanioraochsamhallsvetenskaphs/beredningavansokningar/hanteringavsarskildautlysningarkulturforskningrambidrag20I0.4.ead945 bi If699b50858000I9430.html (2OII-OI-I 2 ).

Welinder, S. 2003. Min svenska arkeologihistoria. Ett ekonomiskt och socialt perspektiv på I 900 -talet. Lund: Studentlitteratur.

Wobst, M.H. \& Smith, C. (Ed.). 2005. Indigenous Archaeologies. Decolonising Theory and Practice. London: Routledge.

Åkesson, J. 2009. Muslimerna är vårt största utländska hot. Aftonbladet. 09-I0-I9.

Åkesson, J. 20I I. Dags att studera islamitiska attityder bland ungdomar. Dagens Nyheter. II-OI-25. 